\title{
Design, calibration and testing of precise magnetometers
}

\author{
Primdahl, Fritz; Merayo, José M.G.; Brauer, Peter; Risbo, T
}

Published in:

Proceedings of IEEE Sensors, 2003.

Link to article, DOI:

10.1109/ICSENS.2003.1278981

Publication date:

2003

Document Version

Publisher's PDF, also known as Version of record

Link back to DTU Orbit

Citation (APA):

Primdahl, F., Merayo, J. M. G., Brauer, P., \& Risbo, T. (2003). Design, calibration and testing of precise magnetometers. In Proceedings of IEEE Sensors, 2003. (Vol. 1). IEEE.

https://doi.org/10.1109/ICSENS.2003.1278981

\section{General rights}

Copyright and moral rights for the publications made accessible in the public portal are retained by the authors and/or other copyright owners and it is a condition of accessing publications that users recognise and abide by the legal requirements associated with these rights.

- Users may download and print one copy of any publication from the public portal for the purpose of private study or research.

- You may not further distribute the material or use it for any profit-making activity or commercial gain

- You may freely distribute the URL identifying the publication in the public portal 


\section{Design, Calibration and Testing of Precise Magnetometers}

\section{Fritz Primdahl}

Danish Space Res. Inst. and Oersted-DTU, DK-2800 Kgs. Lyngby

Denmark.

fpr@oersted.dtu.dk

\author{
J.M.G. Merayo \\ Oersted-DTU, Meas. \& \\ Instrumentation Syst. \\ DK-2800 Kgs. Lyngby \\ Denmark. \\ jmm@oersted.dtu.dk
}

\author{
Peter Brauer \\ Oersted-DTU, Meas. \& \\ Instrumentation Syst. \\ DK-2800 Kgs. Lyngby \\ Denmark. \\ pb@oersted.dtu.dk
}

\author{
Torben Risbo \\ Dept. of Geophysics \\ Copenhagen Univ. \\ DK-2100 Copenhagen \\ Denmark \\ tr@gfy.ku.dk
}

\section{Keywords}

Vector Magnetometer, Scalar Magnetometer, Stellar camera, Space Magnetic Measurement.

\begin{abstract}
The requirements for precise global mapping of the Earth's vector magnetic field from a LEO satellite are discussed.
\end{abstract}

\section{Introduction}

The Earth's magnetic field has been precisely mapped from space, first by NASA's Magsat Mission in 1979 1980 [1] and 20 years later, as part of the IAGA International Decade of Geopotential Field Research [2], by the Danish Ørsted Mission (1999 -) [3], the German CHAMP Geopotentials Mission (2000 -) [4] and by Ørsted-2, the Danish MMP (Magnetic Mapping Payload) onboard the Argentine-US SAC-C Earth observation satellite (2000 -) [5]. Several missions are under study for continuing the International Decade of Geopotential Field Research; such as ESA's SWARM Mission and others.

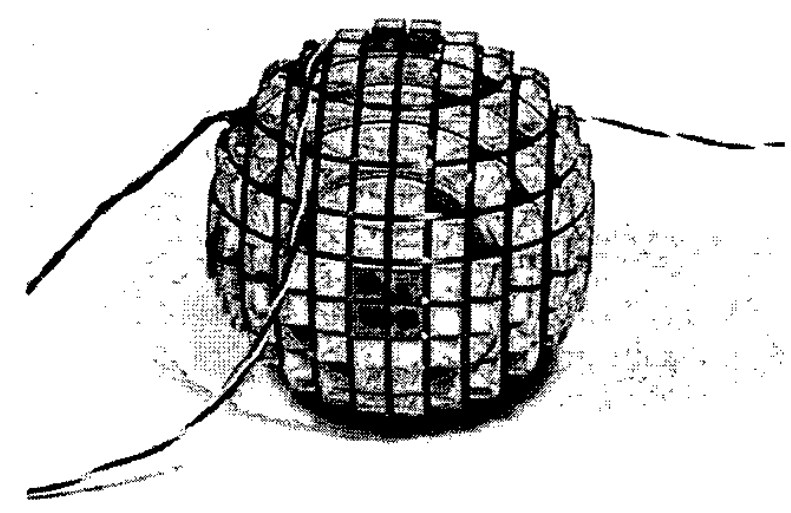

Figure 1. The Oersted.DTU/DSRI CSC Compact Spherical Coil tri-axial vector feedback sensor.

\section{Precise Magnetic Vector Field Measurements from Space}

Magnetic field determination in space requires a combination of vector data, attitude, position and time. Three instruments provide this: a high-precision vector magnetometer, an absolute attitude determination system in term of a star camera and a GPS receiver. In addition, a precision attitude transfer system between the star camera and the vector magnetometer must be provided, and an absolute scalar magnetometer is needed for inflight calibration of the vector magnetometer offsets, scale values, etc. The Danish CSC tri-axial vectorfeedback magnetometer [6] (see Fig. 1) has performed the magnetic vector-field mapping task on the recent missions together with the Danish Advanced Stellar Compass system.

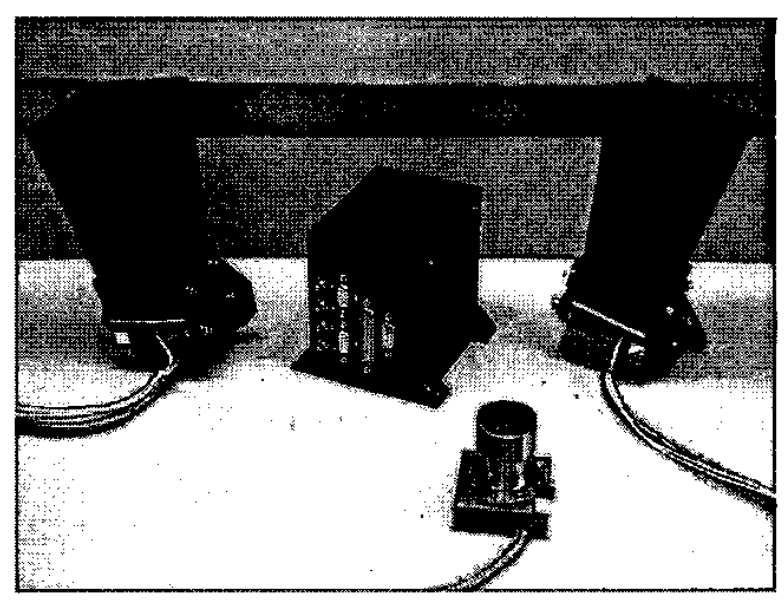

Figure 2. The Oersted-DTU $\mu$-ASC Micro Advanced Stellar Compass system.

The Oersted.DTU Micro Advanced Stellar Compass [7] (see Fig. 2) successfully provides absolute arc sec inertial attitude on eight missions and will fly on ten more in near future. For in-orbit vector magnetometer 
calibration, a scalar field data rate of only about one per minute or less is required [8], and of all the nuclear and electron spin resonance magnetometers the omnidirectional toroid-sensor Proton Free Precession magnetometer [9] (see Fig. 3) is the simplest,

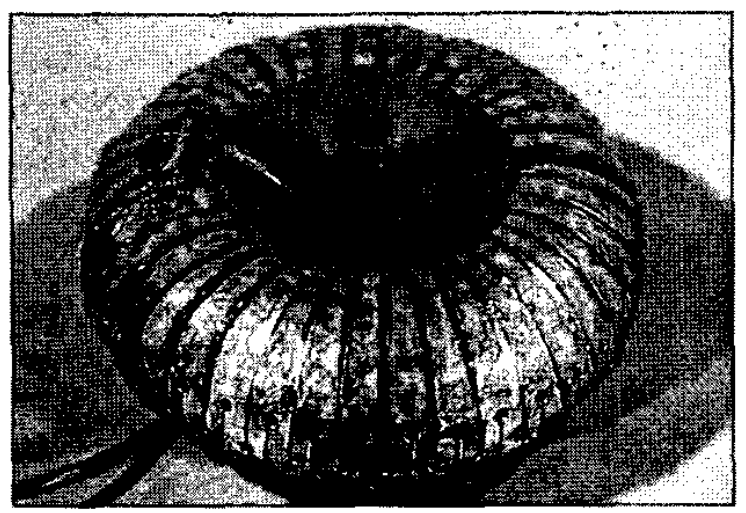

Figure 3. The Oersted-DTU/DSRI Toroidal omnidirectional Proton Free Precession scalar sensor.

the closest to being absolute and the most resource effective at low data rates. The local satellite magnetic environment is equally important as a high quality of the instruments. A well-designed field-mapping mission requires careful compromises between the sensors' boom deployment length, spacecraft ac/dc magnetic cleanliness and arc sec-level stability of the mechanical attitude transfer between the star camera and the vector magnetometer sensor. Pre-flight (and in-flight) instrument calibrations and inter-calibrations [10] need to be carefully planned and performed, and the accuracy of the overall absolute timing and the relative timing between the instruments is of equally vital importance for the success of the data analysis.

\section{References}

[1] R.A. Langel, G. Ousley, J. Berbert and M. Settle, The MAGSAT mission, Geophys. Res. Lett., 9, 243-45, 1982.

[2] IAGA-97 Resolution \#1: "International Decade for Geopotential-Field Research", IAGA News, No. 37, page 17, December 1997.
3] T.Neubert, M. Mandea, G. Hulot, R. von Frese, F. Primdahl, J.L. Jørgensen, E. Friis-Christensen, P. Stauning, N. Olsen and T. Risbo, Ørsted Satellite Captures High-Precision Geomagnetic Field Data, EOS, Transactions, 82, no. 7, 81, 87-88, AGU, 2001. [4] Christoph Reigber, Hermann Lühr and Peter Schwintzer (eds.), First CHAMP Mission Results of Gravity, Magnetic and Atmospheric Studies, Springer Verlag, Berlin Heidelberg, Gemany, 2003.

[5] Per Lundahl Thomsen, Carlos Alonso, Carlos Hoffmann, Danish Participation in the Argentine SAC-C Satellite Mission, in: H.P. Röser, R. Sandau and A. Valenzuela (eds), Small Satellites for Earth Observation, Symp. of the International Academy of Astronautics Berlin, November 4-8, 109-112, Walter de Gruyter \& Co., Berlin, Germany, 1996.

[6] O.V. Nielsen, J.R. Petersen, F. Primdahl, P. Brauer, B. Hernando, A. Fernandez, J.M.G. Merayo, and P. Ripka, Development, Construction and Analysis of the "ØRSTED" Fluxgate Magnetometer, Meas. Sci. Technol., 6, 1099-1115, 1995.

[7] John Lejf Jørgensen, Troelz Denver, Maurizio Betto, Pieter Van den Braembussche, The PROBA Satellite Star Tracker Performance, in: H.P. Röser, R. Sandau and A. Valenzuela (eds), Small Satellites for Earth Observation, $4^{\text {th }}$ Symp. of the International Academy of Astronautics, Berlin, April 7-11, 201-206, Wissenschaft und Technik Verlag, Berlin, Germany, 2003

[8] N. Olsen, Lars Tøffner-Clausen, Terence J. Sabaka, P. Brauer, José M.G. Merayo, John L. Jørgensen, J.-M. Léger, Otto V. Nielsen, Fritz Primdahl and T. Risbo, Calibration of the Oersted Magnetometer, Earth Planets Space, 55, 11-18, 2003.

[9] F. Primdahl, Resonance Magnetometers, in: Pavel Ripka (ed.), Magnetic Sensors and Magnetometers, 267304, ARTECH HOUSE INC., 2000.

[10] T. Risbo, P. Brauer, J.M.G. Merayo, O.V. Nielsen, J.R. Petersen, and F. Primdahl, Ørsted Pre-Flight Magnetometer Calibration Mission, Meas. Sci. and Technol., 14, 674-88, 2003. 